A N N A LE S

UNIVERSITATIS MARIAE CURIE-SKŁODOWSKA

LUBLIN - POLONIA

\title{
KAROLINA WIEREL
}

Uniwersytet w Białymstoku

\section{Postapokaliptyczna wizja człowieka w trylogii Dmitra Głuchowskiego: Metro 2033, Metro 2034, Metro 2035}

Post-apocalyptic vision of man in novels by Dmitry Glukhovsky: Metro 2033, Metro 2034 and Metro 2035

Nic, co ludzkie nie utrzyma się w najbliższej przyszłościํ.

W literackiej trylogii Metro 2033, Metro 2034 i Metro 2035 Dmitrij Głuchowski przedstawił bogate spektrum możliwych postaw ludzi w alternatywnym świecie, w którym era antropocenu dobiegła do gwałtowanego końca. Opowieści zawarte w trylogii dotyczą historii rzekomo ostatniej enklawy ludzkiej na świecie, żyjącej w podziemiach moskiewskiego metra. Nieliczni szczęśliwcy, którzy przeżyli wojnę nuklearną, próbują przystosować się do nowych realiów egzystencji i niestrudzenie chcą przeżyć. Nowe pokolenia kolonizatorów moskiewskiego metra wyobrażenia o świecie na powierzchni czerpią z opowieści, literatury, starych gazet oraz ilustracji. Jest to świat wyobrażony, można rzec nawet - mityczny. Rosyjski pisarz stworzył postapokaliptyczną wizję rzeczywistości, opartą na archetypicznych motywach walki dobra ze złem, piękna z brzydotą, światła i mroku. Głuchowski posłużył się motywami mitycznymi do budowania wielu poziomów znaczeń fabuły trylogii. Jednym poziomem jest świat, jaki wyłania się z wypowiedzi mieszkańców metra, w ich rozmowach, opowieściach,

${ }^{1}$ N. Land, Fanged Noumena: Collected Writings 1987-2011, Nowy Jork 2011, s. 443, cyt. za: R. Mackey, Nick Land - antyhumanistyczny eksperyment, przeł. K. Rychter, „Kronos” 2015, nr 3, s. 101. 
refleksjach. Inny obraz postapokaliptycznego świata opisał narrator, a jeszcze inny ukazano w formie gry motywami kulturowymi, którą autor prowadzi z czytelnikiem.

Począwszy od sprowadzenia ludzi do podziemi, przez mesjańskość losów Artema, po filozoficzne rozważania o człowieczeństwie, w każdym przypadku toczy się nieustanna gra wyobrażeniami o świecie i człowieku czytelnika i narratora Metra. W mojej opinii celem owej kulturowej gry Głuchowskiego może być poszukiwanie granic czyniących z ludzi istoty uczłowieczone. Postaram się wskazać, jakie wyobrażenia o pozycji ludzi w postapokaliptycznym świecie pisarz ukazał w trylogii i jakie są jego propozycje odpowiedzi na pytanie, co to znaczy być człowiekiem w świecie „po końcu”. Jest to pytanie nie o kondycję człowieka w postapokaliptycznym świecie, lecz o to, czy człowieczeństwo ocalało razem z ludźmi.

Nawiązania do mitologii i gra tradycjami kulturowymi we wszystkich trzech częściach Metra są stałymi punktami odniesienia w kreacji postaci: Homera, Artema, Huntera, Leonida i Saszy. Wszyscy żyją w mrocznych czasach „podziemnej” historii człowieka. Chtoniczna rzeczywistość moskiewskiego metra przywołuje skojarzenia z powrotem ludzi do źródeł istnienia, czyli do prochu ziemi, i uruchamia bogactwo infernalnej symboliki. Analizę mitologii w ujęciu motywów chtonicznych odnajdziemy w tekstach Mircei Eliadego. Badacz w analizie kultur mezopotamskich przywołuje opowieści kosmogoniczne, w których występuje określenie ziemi jako matrix mundi (macierz powszechna) ${ }^{2}$. Z ziemi wywodzi się człowiek, który został ulepiony z gliny, prochu, piasku i łez bogów. Motyw ulepienia człowieka przez bogów/Boga jest obecny w wielu mitologiach, zarówno w antycznej ${ }^{3}$, jak i w judeochrześcijańskiej ${ }^{4}$ Obie tradycje mitologiczne współtworzą wyobrażenia o boskim rodowodzie człowieka w kulturach Zachodu $^{5}$. Są też polem do budowania znaczeń w fabułach postapokaliptycznych, jak ma to miejsce u Głuchowskiego. Zakorzenienie trylogii w kontekście mitologicznym może skierować interpretację serii Metro w rejony archetypicznych znaczeń, które łączą się z kosmogonicznymi opowieściami o początkach stworzenia, o kreacji ludzi z gliny i wody, z kosmicznego pyłu i boskiego oddechu. Opowieści chtoniczne o początkach ludzkości zakorzeniają postapokaliptyczną wyobraźnię w bogactwie mitologicznych odniesień i na niej budują kolejne znaczenia,

${ }^{2}$ M. Eliade, Kowale i alchemicy, przeł. A. Leder, Warszawa 2007, s. 43.

${ }^{3}$ Według wierzeń starożytnych Greków Prometeusz ulepił ciało człowieka z gliny i łez, a duszę tchnął ze słonecznych iskier. Vide: R. Graves, Mity greckiej, przeł. H. Krzeczkowski, Kraków 2009; J. Parandowski, Mitologia i wierzenia Greków i Rzymian, Poznań 1987.

${ }^{4}$ Vide: Rdz, 2,7, loc. cit: Pismo Święte Starego i Nowego Testamentu, [na:] http://biblia.deon. pl/rozdzial.php?id=2 [data dostępu: 10.04.2016].

${ }^{5}$ Vide: M. Schipper, Na początku nie było nikogo: jak pojawili się ludzie?, przeł. R. Pucek, Warszawa 2012. 
prowadzą grę wyobrażeniami dotyczącymi człowieka i człowieczeństwa, prawdy i kłamstwa, piękna i brzydoty, a także tego, co dobre, prawdziwe i sprawiedliwe. Postmodernistyczna konwencja gry z tradycjami w literaturze postapokaliptycznej nie służy tylko zakwestionowaniu reguł porządkujących świat czytelnika i krytyce kultury Zachodu. W mojej opinii twórczość Głuchowskiego wpisuje się w nurt propagujący idee nowej humanistyki, w ramach czego wyeksponowane zostają problemy, takie jak zmiana granic człowieczeństwa, kategorii życia, relacji ludzi i nie-ludzi, czego efektem ma być uwrażliwienie odbiorcy kultury Zachodu na nie-antropocentryczne wizje świata. Za Bruno Latourem można mówić o „unerwianiu” człowieka na zmianę relacji z przyrodą i nowymi istnieniami, takimi jak obecne w trylogii Metro hybrydy transgatunkowe czy formy inteligencji inne niż ludzka. Już z pierwszych stron (o)powieści Głuchowskiego dowiadujemy się o istnieniu przerażających istot nazwanych przez mieszkańców metra Czarnymi. Ze względu na diaboliczny kolor skóry i przerażające dźwięki Czarni przypominać mogą postaci z najstraszniejszych baśni o diabłach, koszmarów, czy horrorów. Łącznikiem między ludźmi a nowymi istotami jest Artem. Relacje Artema z Czarnymi nie przedstawiają człowieka w pozytywnym świetle, co staje się szczególnie widoczne w zakończeniu pierwszego tomu trylogii. Artem, traktowany przez Czarnych jak Wybraniec, ostatecznie przyczynia się do ich zagłady. Brak wrażliwości Artema na „inność” staje się destrukcyjną siłą istoty ludzkiej, która jawi się w pierwszym tomie jako niezdolna do nawiązania porozumienia i szacunku wobec istot równie inteligentnych jak człowiek, nie będących ludźmi.

Uważam, że propagowanie szacunku dla innych niż ludzkie form życia czy zwrot ku harmonii z przyrodą, jakie dostrzegam w fabułach uniwersum $\mathrm{Me}$ tra, można uznać za próbę przezwyciężenia myślenia opartego na postmodernistycznej metaforyce „kryzysu”: humanistyki, nauki, przyrody i człowieczeństwa. Wrażliwość postapokaliptyczna u Głuchowskiego oparta jest na kapitale postmodernistycznym, ale niewątpliwie twórca trylogii wykracza poza pesymistyczne scenariusze przyszłości. Za sprawą obecności myśli ekologicznej i postsekularnej w twórczości postapokaliptycznej kreacje postaci u Głuchowskiego otwierają wyobraźnię czytelnika na człowieka i rozumienie człowieczeństwa w ujęciu nieantropocentrycznym. W omawianych książkach dostrzegam atmosferę nadziei na odmianę losu ludzi żyjących po katastrofie, czego zapowiedzią może być zakończenie trylogii, gdzie Artem, wraz z grupą kolonizatorów, wychodzi na powierzchnię, aby odnaleźć innych ocalałych i spróbować życia ,pod gwiazdami”. Głuchowski, czerpiąc z chtonicznego pochodzenia człowieka, stara się dowieść, że miejscem życia ludzi jest powierzchnia Ziemi, a nie jej wnętrze. Artem, Ania, Leonid, Homer i Sasza marzą o życiu na powierzchni, gdyż dzięki temu mogą ocalić swoje ludzkie miano i w pełni rozwijać to, co nazwać można człowieczeństwem. 
Za Fryderykiem Nietzschem można powiedzieć, iż na tle kanibali, praktyk kazirodczych, sekt i wojen ideologicznych występujących w metrze młodzi bohaterowie są ,arystokracją ducha”. ${ }^{\circ}$. Chaos nowego świata, w którym człowiek utracił uprzywilejowane miejsce jest analogiczny do zamętu w psychice ludzi żyjących po katastrofie. Antropocentryczny ład świata został zastąpiony chaosem. Posługując się terminem Felixa Guattari, nowy świat „po końcu” można nazwać „chaosmozą”, w której podstawą chaosu jest „szczególna tekstura ontologiczna”. Współegzystowanie w przestrzeni różnych organizmów prowadzi do zwątpienia w wyjątkowość człowieka i jego uprzywilejowane miejsce w przyrodzie, na Ziemi i w kosmosie. W takiej sytuacji niezbędne staje się wyznaczenie nowych granic ontologicznych, aksjologicznych i epistemologicznych, czyli zakreślenie tego, co świat oraz istnienie czyni „ludzkim”.

Kwestia człowieczeństwa to główny temat konstrukcji literackich fabuł i narracji o świecie istniejącym w ciemnych zakamarkach moskiewskiego metra. W niniejszej wypowiedzi eksponuję postacie, takie jak Artem, Homer czy Sasza, które reprezentują odrębny, ,inny” typ ludzi - zbuntowanych i wolnych. Owi ludzie w moim przekonaniu najwyraźniej odzwierciedlają przemiany, jakim uległo człowieczeństwo w literackim Metrze.

W uniwersum Głuchowskiego ludzie zostali wychowani na wzorcach bohaterów antycznych, bajkach, legendach i artefaktach minionej kultury, skupionych na gloryfikacji tego, co stworzył człowiek siłą inteligencji. Mity starożytnej Grecji i inne opowieści, które przeczytali lub usłyszeli mieszkańcy metra, ukształtowały ich wyobraźnię kolektywną ${ }^{8}$. Wydaje się, że człowiek Głuchowskiego nie ma możliwości wyboru, gdzie ma żyć. Ludzie mieszkający w podziemiach są świadomi, że nie jest to dobre miejsce do bytowania, lecz ten obcy, „nieludzki" świat staje się wygodną przestrzenią, ich domem, jak stwierdza Artem w zakończeniu pierwszej części trylogii pt. Metro $2033^{9}$. Ów bohater zmienia jednak zdanie w ostatnim ogniwie serii - opuszcza podziemia i wyrusza w nieznane. Co sprawiło, że Artem zmienił zdanie o podziemnym świecie? Dlaczego dom zaczął postrzegać jak piekło?

Los Artema można skonfrontować ze słowami Emmanuela Levinasa, który stwierdził, że duch ludzki objawia się w świadomości, że wolność jest zagrożona ${ }^{10}$. Większość żyjących w postapokaliptycznym metrze wybiera najłatwiejszą

${ }^{6}$ Confer: F. Nietzsche, Z genealogii moralności, przeł. G. Sowiński, Kraków 2011.

${ }^{7}$ F. Guattari, Schizochaosmoza, przeł. Michał Gusin, „Kronos” 2015, nr 4, s. 12. Ową „,szczególną teksturę ontologiczną" dostrzegam zarówno w nurcie twórczości postapokaliptycznej, jak i w fantastyce naukowej i fantasy.

${ }^{8}$ D. Głuchowski, Metro 2033, przeł. P. Podmiotko, Kraków 2010, s. 289.

${ }^{9}$ Ibidem, s. 591.

${ }^{10}$ E. Levinas, Całość i nieskończoność, przeł. M. Kowalska, J. Migasiński, Warszawa 2002, s. 20 . 
formę egzystencji, czyli przeżycie w świecie kłamstw, manipulacji i upodlenia człowieka w imię tzw. normalności. Dlaczego ludzie wolą być kanibalami, niż coś zmienić? To jest pytanie, jakie stawia przed czytelnikiem Głuchowski.

Świat znajdujący się powyżej podziemnych korytarzy mieszkańcy moskiewskiego metra postrzegają jako niedostępny, obcy i niebezpieczny. Być może dlatego odrzucają możliwość powrotu na powierzchnię. Świat powyżej korytarzy moskiewskiego metra jest przestrzenią podlegającą mitologizacji. Żyją w nim dziwne, nowe stwory, zazwyczaj żywiące się ludźmi i mające za nic kulturotwórczy wkład ludzkości w historię Ziemi. Przykładem takich wyobrażeń może być rozmowa Leonida z Saszą w Metrze 2034:

Widziałaś kiedyś gwiazdy? Nie - odpowiedziała. Ja też tylko na zdjęciach. Nawet słońce ledwo przebija przez pył i chmury, gwiazdy nie mają na to sił. [...] Kto w takim razie kiedyś na nas patrzył tym tysiącem oczu? I dlaczego przestał? [Leonid - uzup. K. W.] - Tam nigdy nikogo nie było - Sasza potrząsnęła głową. - A ja zawsze chciałem wierzyć, że ktoś nas pilnuje ${ }^{11}$.

Rozmowa kobiety i muzyka świadczy o stale obecnych w ich wyobraźni myślach i pragnieniach opartych na woli kontaktu z siłą wyższą, symbolicznie wyobrażaną pod postacią Poruszyciela, który czuwa nad ludzkością i każdym z osobna. W podziemiach nie ma możliwości patrzenia w niebo, nie widać gwiazd, ale nadal istnieją o nich wyobrażenia czerpane z opowieści, z ilustracji i z książek. Bogowie istnieją, ale w zdeformowanych formach, takich jak bogowie-kanibale, „bogowie telefoniczni”'12. W roli bogów stawiają się też naukowcy prowadzący eksperyment na ludziach w celu zbadania ich wytrzymałości na ból i cierpienie, niczym w historii o Bogu i Hiobie ${ }^{13}$. Mieszkańcy metra są samotni, czują się porzuceni i to przekonanie jest dziedziczone przez kolejne pokolenia urodzonych pod ziemią. Ludzie opowiadają sobie o życiu sprzed katastrofy, słuchają historii osób pamiętających życie na powierzchni. Głównie za pomocą słów kształtowane są kolejne pokolenia wyobrażeń zbiorowych o przeszłości. Nieliczni w metrze czytają, gdyż ta umiejętność uważana jest za elitarną z uwagi na brak stałego i wystarczającego źródła światła, tylko w stacjach nazywanych Polis zachował się szacunek do książek i słowa drukowanego. Na podstawie losów Homera można stwierdzić, iż humanizującą siłę kształtowania wyobrażeń o świecie w trylogii Głuchowskiego upatruje się w piśmienności. Starzec marzy, aby napisać nowy epos dla mieszkańców metra, gdyż wierzy, że dopóki ludzie czytają i szanują książki, dopóty są bliżsi temu, co mieści się w granicach człowieczeństwa, za sprawą obcowania z kulturą pisma i druku oddalają się od regresu ludzkiej moral-

${ }^{11}$ D. Głuchowski, Metro 2034, przeł. P. Podmiotko, Kraków 2010, s. 400.

${ }^{12}$ Ibidem, s. 468.

${ }^{13}$ „Przykro mi, że budowa kręgosłupa nie pozwala mi zadrzeć głowy do góry i popatrzeć na tego, który przeprowadza eksperyment". Vide: ibidem, s. 473. 
ności. W opinii Homera problem człowieka tkwi w tym, że chce czytać i słuchać baśni, a nie prawdy o sobie i świecie.

Mieszkańcy poszczególnych stacji reprezentują bogactwo ludzkich postaw, idei, marzeń i pragnień. Społeczność stacji Polis różni się od ludzi z pozostałych stacji $^{14}$. Zauważa to Artem, który przybywa ze stacji WOGN i opisuje to, co widzi w następujący sposób:

Dziwnie było patrzeć na całkowicie oświetloną stację metra. W ogólnie nie było tu cieni. I na WOGN-ie, i na wszystkich innych stacjach i stacyjkach, które do tej pory miał okazje odwiedzić, źródeł światła było niewiele, i nie mogły one oświetlić całej widocznej przestrzeni [...]. Wszędzie były miejsca, do których nie przedostawał się ani jeden promień światła. Każdy człowiek miał kilka cieni. [...] A w Polis nieubłagane lampy światła dziennego unicestwiły wszystkie cienie, co do jednego ${ }^{15}$.

Czytając o spostrzeżeniach Artema, nie można oprzeć się wrażeniu, że w jego słowach kryje się alegoryczne rozumienie słów „cień”, „mrok”, „światło” czy „promień”. Ilość światła, czystość, porządek w Polis kontrastują z rzeczywistością na innych stacjach, wpływają również na sposób życia ludzi zamieszkujących każdą ze stacji, na ich moralność, relacje i sposób myślenia. Można pokusić się o stwierdzenie, że ilość światła czyni człowieka lepszym, bardziej ludzkim i bliższym człowieczeństwu. Mrok, chaos, podziemia oddalają ludzi od kultury i czynią ich bytami okołoludzkimi. Atawistyczny lęk człowieka przed ciemnością i dążenie ku światłu potwierdzają kolejne spostrzeżenia Artema po przybyciu do Polis:

Artem pierwszy raz widział coś takiego. Od tych mieszkań czuć było takie ciepło, taki spokój, że aż ścisnęło mu się serce. [...] ale najbardziej zadziwiające było to, że wzdłuż ścian, na całej stacji ciągnęły się rzędy regałów z książkami. Zajmowały miejsce między mieszkaniami i cała stacja nabrała przez to jakiegoś cudownego, nieziemskiego wyglądu, przypominając Artemowi opis bibliotek w średniowiecznych uniwersytetach, o których czytał w książce pisarza o nazwisku Borges ${ }^{16}$.

Świat stacji Polis jest tak nierealny, jak ten z lektur Artema, które według niego nie odzwierciedlają prawd życiowych i są nieadekwatne do losów człowieka. Bohater stwierdza, że „po przeczytaniu sporej ilości książek może powie-

${ }^{14}$ Przykładem typowych relacji międzyludzkich w moskiewskim metrze może być konflikt między stacjami opanowanymi przez faszystów, zwanych IV Rzesza, a stacjami komunistów zamieszkujących Linię Czerwoną. Konflikt przypomina wydarzenia historyczne i czerpie z dziejów kultur Zachodu z czasów pierwszej połowy wieku XX, a szczególnie z okresu II wojny światowej. Innym nawiązaniem do kulturowej spuścizny Zachodu jest sojusz gospodarczo-polityczny stacji o nazwie Polis, nawiązujący do demokratycznych tradycji starożytnej Grecji.

${ }^{15}$ D. Głuchowski, Metro 2033, s. 339.

${ }^{16}$ Ibidem, s. 339. 
dzieć, iż w nich wszystko jest nie tak jak w życiu. [...] Chodzi o to, że życie nie ma fabuły?" ${ }^{17}$. Kwestia relacji między słowem a pismem odzwierciedla spór między różnymi formami wyobrażeń o świecie - tymi ukształtowanymi przez słowo i przez obraz. Spór o znaczenie mimesis w literaturze to konflikt tego, co prawdziwe z tym, co wyobrażone, co bliższe człowiekowi i jego życiu, z tym, co ,sztuczne" i co oddala ludzi od siebie i czyni bytem nieokreślonym. Pamiętać jednak należy, iż za sprawą kultury opartej na piśmienności w wyobraźni mieszkańców metra pozostał obraz świata sprzed wojny atomowej. Jest to świat przewidywalny i ukształtowany wedle ludzkich potrzeb. Za pomocą fikcji literackich zaszczepiane są fantasmagorie o minionym świecie i o tym obecnym na powierzchni. W baśniach, eposach czy mitach przekazywane są wartości ponadczasowe, takie jak szacunek do życia, idee ludzkiej wolności i godności życia.

Mieszkańcy Polis jako jedyni wyprawiali stalkerów na powierzchnię po książki, gdyż tylko mieszkańcy stacji przynależnych Polis wiedzę cenili jako dobro duchowe i byli gotowi ryzykować dla niej życie poszukiwaczy ${ }^{18}$. Nadmienić należy, że Głuchowski ożywia postać stalkera, czerpiąc inspiracje z kultowego obecnie wśród sympatyków fantastyki Pikniku na skraju drogi Arkadija i Borisa Strugackich ${ }^{19}$. W literackiej serii pisarza stalkerzy są oddzielną i uprzywilejowaną grupą ludzi wśród mieszkańców moskiewskiego metra. Jednym z nich stał się Artem, wzorując się na Hunterze i Młynarzu. Stalkerzy stworzyli organizację zwaną Zakonem, której celem była obrona mieszkańców metra przed różnymi zagrożeniami. Głuchowski w powieściach Metro 2033, Metro 2034 i Metro 2035 uczynił stalkerów łącznikami ze światem na powierzchni i jednymi z głównych postaci charakteryzujących postapokaliptyczny świat. W utworach tworzących uniwersum Metra stalkerzy stają się na tyle znaczącym elementem konstrukcji fabuł, iż wokół nich budowane są losy innych postaci. Stalkerami są uzbrojeni i wytrenowani poszukiwacze pozostałości dawnego świata. Znalezione i przyniesione do podziemi rzeczy pomagają ludziom przetrwać w niekorzystnych warunkach.

Każdy stalker był człowiekiem legendą, półbogiem, na którego wszyscy - od małych po wielkich - patrzyli w zachwycie. Kiedy rodzą się dzieci w świecie, w którym nie ma już dokąd i po co latać i żeglować, a słowa „lotnik” i „marynarz” zacierają się i stopniowo tracą swój sens, dzieci te chcą zostać stalkerami. Wychodzić odzianym w lśniącą zbroję, gdy odprowadzają cię setki pełnych zachwytu i uwielbienia spojrzeń, wychodzić na górę, do bogów, by walczyć z potworami i wracając tu, pod ziemię, przynosić ludziom paliwo, amunicję i ogień. Przynosić życie. Stalkerem chciał zostać i Artem, i jego przyjaciel Żeńka ${ }^{20}$.

\footnotetext{
${ }^{17}$ Ibidem, s. 326.

${ }^{18}$ Vide: ibidem, s. 100.

${ }^{19} \mathrm{~W}$ oryginale powieść ukazała się w roku 1972.

${ }^{20}$ Ibidem, s. 45.
} 
W świecie postapokaliptycznym stalkerzy są odpowiednikami mitycznych herosów, dzięki którym życie ludzi jest możliwe w nowych realiach. Dzięki rzeczom przynoszonym z powierzchni podziemny świat metra staje się bardziej oswojony, uczłowieczony, a zmagania z przeciwnościami losu, jak i wewnętrzna walka o ocalenie zasad moralnych i poczucie przynależności do ludzkiej wspólnoty, wydają się mieć sens. Stalkerzy wychodzą na powierzchnię i przez to są postrzegani jako istoty bliższe sferze niedostępnej, budzącej lęk, grozę i szacunek wśród mieszkańców podziemnego świata. To półbogowie, a nawet prometeusze postapokaliptycznego świata. Artem wstępuje do Zakonu, a następnie przeciwstawia się jego władzy.

W pierwszej i drugiej części trylogii los bohatera kształtuje marzenie o byciu podobnym do innych stalkerów, np. Huntera czy Młynarza. W oczach chłopaka stalker to „lepsza” wersja mieszkańca metra. I kiedy wyrusza z rodzimej stacji WOGN, zauważyć można, że wyobrażenia Artema o świecie są ukształtowane przez opowieści i lektury. Czytelnik obserwuje niezwykłą wędrówkę młodego mężczyzny, który podróżuje nie tylko między stacjami, ale i między jawą a snem. Wyprawa Artema przyczynia się do uzyskania przez niego wiedzy o niedoskonałości człowieka i doprowadza go do deziluzji wyobrażeń o stalkerach. Oniryczne wizje bohatera pogłębiają jego stan niezdecydowania, zawieszenia i otępienia. Artem nie ufa snom, przeczuciom, instynktowi i zdaje się niesiony przez los/przeznaczenie. W ostatniej części trylogii sytuacja bohatera ulega zmianie. Czytelnik spotyka buntownika, który sam zaczyna decydować o swoim życiu. Przestaje być „kukiełką losu”. Jednak zanim to się stało, chłopak doświadczył wielu przygód i spotkał na swojej drodze różne istoty. Głuchowski w historii głównej postaci trylogii ukazał zmianę rozumienia tego, co określa człowieczeństwo oraz proces budowania poczucia wartości bycia człowiekiem. Przemiana rozpoczyna się od dążenia Artema do próby realizacji mitów w życiu, co okazuje się niemożliwe. Bohater po traumie wywołanej zagładą Czarnych odradza się jako nowa istota - wolna od uprzedzeń, szanująca życie we wszelkich jego przejawach, godna miana człowiek.

W korytarzach moskiewskiego metra mamy do czynienia z przemianą wyobrażeń o człowieku i człowieczeństwie. Wzorzec postaw ludzkich charakterystyczny dla cywilizacji Zachodu, reprezentowany przez epicką postać Odyseusza, został przeciwstawiony postawie człowieka z opowieści mitologicznych. Potrzebny jest nowy Odyseusz, który nie będzie jednostką wspartą technologiami poskramiającymi przyrodę. Fabuły postapokaliptyczne obnażają anachroniczność wzorca bohatera eposu antycznego. W opinii Theodora W. Adorno i Maxa Horkheimera postać Odyseusza jest wcieleniem cech cywilizacji Zachodu. Przeciwwagą tej postawy może być człowiek mitologiczny, przynależny opowieściom 
o stworzeniu świata ${ }^{21}$. Ów binarny układ sił sprawia, iż można przenieść narrację o kulturze i człowieku na dwa typy relacji ludzi z naturą. Pierwszy typ reprezentuje Odyseusz, którego postawę wobec przyrody odnajduję także w postaciach stalkerów i zarządców podziemnego świata. Ich celem jest poskromienie życia w imię dobra człowieka. Drugi typ nie jest heroiczny i oparty na przemocy wobec natury. W losach Artema skonfrontowane zostają pojęcia bohatera i antybohatera. Stał się on bohaterem dla ludzi z metra, kiedy ocalił ich przed Czarnymi. Jednak w tym samym momencie ów „bohater” zaprzepaścił szansę, jaką dała człowiekowi natura. Po zniszczeniu osady Czarnych Artem przez moment poczuł się elementem jednego organizmu, organizmu świata. Wizja ta jest momentem deziluzji - tak mogłoby być, ale nie będzie. Dlaczego? Gdyż człowiek jest gatunkiem samotniczym, niezdolnym do porozumienia ponadgatunkowego. Odyseuszowa „chytrość” w przezwyciężaniu planów bóstw, reprezentujących siły Natury, u Głuchowskiego przybiera postać człowieka, który w momencie przełamania horyzontu antropocentrycznego przestaje być epickim bohaterem. W trzeciej części trylogii zostaje to podkreślone niechęcią Artema do rozmnażania i przedłużania gatunku ludzkiego, który żyłby w podziemiach. Nie chce, by jego dzieci podzieliły los mieszkańców metra. Jego życie przypomina dzieje Prometeusza, który pragnie podarować ludziom światło słońca i gwiazd, przez co jest uważany za szaleńca. Perspektywa opuszczenia korytarzy metra i powrotu na powierzchnię przedstawiona przez zbuntowanego stalkera nie spotyka się z entuzjazmem mieszkańców podziemnego świata. Artem jest nazywany „wariatem”, „świrem”, „obłąkańcem” głównie przez ludzi zarządzających stacjami, obawiających się utraty władzy i zachwiania swojej pozycji. Jeden z faszystów stwierdza, iż powrót na powierzchnię to nie jest dobry pomysł ${ }^{22}$. Niechęć wobec idei powrotu na powierzchnię może wynikać z obawy władz stacji i stalkerów o utratę uprzywilejowanej pozycji. Wiązałoby się to z koniecznością powrotu do zasad kulturowych sprzed katastrofy, np. dotyczących zakazu kazirodztwa i kanibalizmu oraz nakazu poszanowania życia. Ciemne korytarze lepiej chronią ludzkie zbrodnie i pozwalają unikać odpowiedzialności. Postawa „zgiętego kręgosłupa” mieszkańców metra zdaje się przekładać na ich system moralny, który staje się coraz bardziej rozchwiany i względny.

W drugim i trzecim tomie trylogii pojawia się motyw bezpośrednio nawiązujący do tradycji epickiej czasów antycznych. Występuje w nich postać Homera. Niczym antyczny pieśniarz starzec mieszkający w podziemiach metra pragnie

${ }^{21}$ T. W. Adorno, M. Horkhaimer, Dialektyka oświecenia, przeł. M. Łukasiewicz, Warszawa 2010, s. 40.

${ }^{22}$ „A co myślisz, że jeśli cię wypuszczę to zaraz całe metro wyjdzie za tobą na górę? Porzucisz nas, powiesz ludziom prawdę i poprowadzisz ich za sobą na powierzchnię? I wszystko tam będzie inaczej niż tu? [...] Zdajesz sobie chociaż sprawę, że będziesz wszystkim powtarzać bajkę o Niewidzialnych Obserwatora? Ocknij się Artem”. Vide: D. Głuchowski, Metro 2035, s. 125 [wersja pdf]. 
napisać epopeję o bohaterach swojego świata. Za jej przyczyną „Homer z metra” chce zaszczepić w przyszłych czytelnikach etos człowieczeństwa. Marzy też, by stać się następcą twórcy antycznych eposów, jednak los nie sprzyja Homerowi i z bojownika o człowieczeństwo zmienia się w samotnika i zgorzkniałego, rozczarowanego światem kronikarza. „Homer nie był ani wojownikiem, ani lekarzem, a przede wszystkim był za stary, żeby wierzyć w cuda. Lecz mimo to część jego duszy namiętnie pragnęła cudu, marzyła o ocaleniu"23. Owa nadzieja na ocalenie od zapomnienia pewnych wydarzeń z historii metra ożywa w Homerze po spotkaniu z młodą i waleczną dziewczyną o imieniu Sasza. Ocalona przez starca i stalkera Huntera dziewczyna staje się inspiracją do snucia opowieści o losach nowych bohaterów metra. Z czasem to Sasza zaczyna reprezentować zbiór cech ludzkich, jakie chce ocalić od zapomnienia Homer, takich jak: miłosierdzie, poświęcenie, szacunek do życia. Ludzie nie szanują starszego człowieka, gdyż jest bezużyteczny, a jego przezwisko traktują prześmiewczo. Miano Homera nawiązuje do świata, którego już nie ma, w ten sposób podkreślając jego nieprzystosowanie do rzeczywistości.

Epicka forma i postawa heroicznych postaci w fabułach trylogii Metro stanowi dysonans z rzeczywistością podziemnego świata i skarlałą moralnością ludzi w postapokaliptycznej rzeczywistości. Postawa heroiczna, charakteryzująca epickie fabuły, nie pasuje do podziemnego świata i losu ludzi, którzy myślą przede wszystkim o tym, aby przetrwać, a nie dokonywać heroicznych czynów lub pisać o wzniosłych historiach. Marny los człowieka z metra jest przyczyną trudności, jakie napotyka Homer przy próbach napisania eposu. Metro to inny świat od tego, jaki pamięta i za którym tęskni Homer. Poza tym, aby napisać historię o mieszkańcach podziemi, autor musi doświadczyć życia z ludźmi, zaś do czasu wyprawy z Hunterem starzec swoją wyobraźnię podsycał książkami opisującymi świat, którego już nie ma. Narrator w trylogii Metro, jakby wbrew Homerowi i jego miłości do pisma i literatury, stwierdza, że życie bywa bardziej interesujące od książek, zaś ocalenie człowieczeństwa wymaga często ofiary z siebie.

W rozważaniach Homera czytamy: „Pies jest zdolny i do miłości, i do współodczuwania [...] pies może nawet tęsknić i widzieć sens swojego życia $w$ innym stworzeniu" ${ }^{24}$. Więc co wyróżnia człowieka pośród innych stworzeń? Homer odkrywa, o czym chce pisać. Tematem jego eposu ma być historia o sprytnym zwierzęciu, które znalazło czarodziejską upadłą gwiazdę, iskrę z nieba, połknęło ją i stało się człowiekiem. O tym, jak wykradłszy bogom ogień, człowiek nie poradził sobie z nim i do szczętu spalił świat. I o tym, jak za karę po upływie równo stu wieków ta właśnie iskra człowieczeństwa została mu odjęta, a bez niej nie stał się znowu zwierzęciem, lecz zmienił się w coś o wiele straszniejszego, co nie ma

\footnotetext{
${ }^{23}$ D. Głuchowski, Metro 2034, s. 375.

${ }^{24}$ Ibidem, s. 346.
} 
nawet imienia ${ }^{25}$. Nawiązując do mitu prometejskiego, Homer przedstawia tragizm ludzi, którzy - niczym herosi lub bogowie - często są karani i przez ludzi, i przez bogów. W trylogii rosyjskiego pisarza mit prometejski nie pozostał tylko opowieścią. Losy Artema, Saszy, Homera czy Leonida to nowe opowieści o Wybrańcach, niczym postapokaliptyczni zbawiciele poświęcających się dla ludzkości w walce o godność życia człowieka oraz jego wolność. Głuchowski zdaje się pytać: czy Prometeusz jest potrzebny mieszkańcom metra? czy ludzie żyjący w mroku nadal potrzebują jego daru ognia i ofiary? W nowej rzeczywistości „po końcu” wszystko jest inaczej. To ,świat na opak", gdzie ofiara ocalająca człowieczeństwo nie zawsze będzie spełniona, jak pokazuje życie Saszy czy Leonida.

Byt człowieka mieszkającego w podziemiach przypomina los Syzyfa bezustannie wtaczającego kamień, będący karą za bunt przeciwko przedwiecznym prawom. Mozolny i niekończący się trud wtaczania głazu człowieczeństwa nie zostanie nigdy zakończony i wynagrodzony. Wbrew beznadziejności postapokaliptycznego losu człowieka, przedstawionego w trylogii Metro, postaci, takie jak: Artem, Ania czy Sasza, próbują zawalczyć o inne życie, o ludzką godność i wolność wyboru, zarówno życia, jak i śmierci. Afirmatywne człowieczeństwo, prezentowane w losach głównej postaci, wyraża nadzieję anty-Odyseusza na ewolucję intelektualną i emocjonalną ludzi. Niektóre postapokalipsy, jak trylogia Głuchowskiego, nie są wyłącznie krytyką kultury Zachodu i jego mieszkańców. Los postaci nie przedstawia wyłącznie wizji kolektywnej kary za grzechy ludzkości popełniane wobec przyrody i wszechświata. Nadzieja na oświecenie i odrodzenie człowieczeństwa w ludziach zostaje zaszczepiona czytelnikowi dyskretnie. Ową szansę na ocalenie otrzymali Artem, Homer i Sasza, a każda z tych postaci wykorzystuje tę możliwość inaczej lub z niej rezygnuje, jak Suchy, który nie odważył się na wyprowadzenie mieszkańców stacji WOGN na powierzchnię. Na dramatyczny apel Artema, aby zabrać ludzi z podziemi, Suchy odpowiada: „Po co? [...] Po co wszyscy ci ludzie mają wychodzić z metra i dokądś iść? Oni tu żyją, Artem. Mają tu swój dom. Nie pójdą z tobą. [...] Nie zabierzesz ich z powrotem do tego, za czym tęsknią. A oni nie chcą wracać, tylko wspominać"26. Los człowieka, który boi się spełniać marzenia, czyni z większości mieszkańców moskiewskiego metra istoty bez imienia. Tylko nieliczni odważą się zmienić życie, aby móc nazywać się człowiekiem i poczuć się wolnym.

Nie ma jednej właściwej drogi prowadzącej ku człowieczeństwu, tak jak w metrze nie ma jednego korytarza prowadzącego na powierzchnię, ku światłu. Niektóre podziemne drogi są niebezpieczne, są i takie prowadzące donikąd, a niektórych z nich lepiej unikać. Historie Artema, Saszy czy Homera łączy poszukiwanie wolności, którą jest możliwość wyboru własnej drogi na powierzchnię.

${ }^{25}$ Ibidem, s. 376.

${ }^{26}$ Idem, Metro 2035, przeł. P. Podmiotko, Kraków 2015, s. 534-535. 


\section{BIBLIOGRAFIA}

Adorno W., Horkhaimer M., Dialektyka oświecenia, przeł. M. Łukasiewicz, Warszawa 2010.

Braidotti R., The Posthuman, Cambridge-Malden 2013.

Domańska E., Humanistyka afirmatywna: władza i płeć po Butler i Foucaultcie, „Kultura Współczesna" 2014, nr 4, s. 117-129.

Eliade M., Kowale i alchemicy, przeł. A. Leder, Warszawa 2007.

Głuchowski D., Metro 2033, przeł. P. Podmiotko, Kraków 2010.

Głuchowski D., Metro 2034, przeł. P. Podmiotko, Kraków 2010.

Głuchowski D., Metro 2035, przeł. P. Podmiotko, Kraków 2015.

Graves R., Mity greckiej, przeł. H. Krzeczkowski, Kraków 2009.

Guattari F., Schizochaosmoza, przeł. M. Gusin, „Kronos” 2015, nr 4, s. 9-14.

Land N., Fanged Noumena: Collected Writings 1987-2011, Nowy Jork 2011.

Levinas E., Całość i nieskończoność, przeł. M. Kowalska, J. Migasiński, Warszawa 2002.

Mackey R., Nick Land - antyhumanistyczny eksperyment, przeł. K. Rychter, „Kronos” 2015, nr 3, s. $94-102$.

Nietzsche F., Z genealogii moralności, przeł. G. Sowiński, Kraków 2011.

Parandowski J., Mitologia i wierzenia Greków i Rzymian, Poznań 1987.

Pismo Święte Starego i Nowego Testamentu. Biblia Tysiąclecia, [na:] http://biblia.deon.pl/ [data dostępu: 10.04.2016].

Schipper M., Na początku nie było nikogo: jak pojawili sięludzie?, przeł. R. Pucek, Warszawa 2012.

\section{STRESZCZENIE}

W artykule przedstawiam różnorodne wyobrażenia człowieka w literackiej trylogii rosyjskiego pisarza Dmitrija Głuchowskiego, przedstawione w Metrze 2033, Metrze 2034 i Metrze 2035. Pisarz ukazał losy ludzi żyjących w korytarzach moskiewskiego metra po wojnie nuklearnej. Epicka forma, jaką Głuchowski nadał swojej wizji postapokaliptycznego świata, sprawia, iż postacie z jego powieści reprezentują bogate spektrum możliwych postaw człowieka wobec realiów alternatywnego świata „po końcu”. Artem, Hunter, Sasza czy Homer to postacie wykreowane na antybohaterów, jednakże mogą stać się również bohaterami nowego świata, o ile potrafią przetrwać i pokonać antropocentryczny sposób postrzegania świata. Głuchowski stworzył alternatywną wizję rzeczywistości zbudowaną na archetypicznych motywach walki dobra ze złem, piękna z brzydotą, przypominającą opowieści mitologiczne przedstawiające jak funkcjonuje nowy, postapokaliptyczny świat. Reguły nowej rzeczywistości różnią się od tych, do których przyzwyczajony jest czytelnik. Pisarz wprowadza wiele kulturowych odniesień do historii mitologicznych (Prometeusz, Syzyf, Marduk, Hiob), narracji literackich (Odyseja, Wehikut czasu H. G. Wellsa, Nowy wspaniały świat A. Huxleya, czy Rok 1984 G. Orwella). Kwestia zmienionego rozumienia człowieczeństwa i relacje transgatunkowe są tematami, które w mojej opinii wprowadzają czytelnika w zagadnienia określane w nauce jako nowa humanistyka, skupione wokół kwestii poruszanych w debacie wokół posthumanizmu i postsekularyzmu, a także problemów, jakimi zajmuje się ekologia. Wyobrażenie człowieczeństwa w trylogii Głuchowskiego jest ukryte w mrocznych, tajemniczych i nieznanych korytarzach moskiewskiego metra oraz ludzkiej wyobraźni.

Słowa klucze: postapokalipsa, antropologia, Głuchowski, literatura rosyjska, mitologie współczesności, mit, Prometeusz, Homer, nowa humanistyka, posthumanizm 


\section{SUMMARY}

This article presents a variety of images of a man in the literary trilogy by a Russian writer Dmitry Glukhovsky which he presented in Metro 2033, Metro 2034 and Metro 2035. The writer revealed the fate of the people living in the corridors of the Moscow subway after a nuclear war. The epic form which Glukhovsky gave his vision of a post-apocalyptic world, makes the characters of his novels represent a wide spectrum of possible attitudes of people in the alternative world "after the end." Artem, Hunter, Sasha, or Homer appear to be anti-heroes. However, they can also become heroes of a new world, as long as they can survive and overcome the anthropocentric way of perceiving the world. Glukhovsky created an alternative vision of reality based on the archetypal motifs of struggle between good and evil, beauty and ugliness, which remind of mythological stories, in which he presents how the new, post-apocalyptic world works. The rules of the new reality are different from those to which the reader is accustomed. The writer introduces many cultural references to the mythological stories (Prometheus, Sisyphus, Marduk, Job), or literature narratives (Odyssey by Homer, The Time Machine by H.G Wells, Brave New World by A. Huxley or Nineteen Eighty Four by G. Orwell). In my opinion the issue of a revised understanding of humanity and trans-species relationships are topics which introduce the reader to the issues which in science are reffered to as a new humanities, and which are centered around the issues raised in the debate on post-humanism and post-secularism as well as the problems ecology deals with. Humanity, which Glukhovsky presents in his novels, is hidden in the dark, mysterious and unknown corridors in the Moscow subway and in the human imagination.

Keywords: post-apocalyptic novel, anthropology, new humanism, post-humanism, Glukhovsky, Russian literature, contemporary mythology, myth, Prometheus, Homer, hero/antihero, new humanism, post-humanism 